\title{
Antimicrobial and antioxidant activities of Enterococcus species isolated from meat and dairy products
}

\author{
S. Pieniz ${ }^{a}$, R. Andreazza ${ }^{b, c *}$, B. C. Okeke ${ }^{b}$, F. A. O. Camargo and A. Brandelli $^{e}$ \\ aLaboratório de Microbiologia de Alimentos, Departamento de Nutrição, Universidade Federal de Pelotas - UFPel, \\ Rua Gomes Carneiro, 1, CEP 96010-610, Pelotas, RS, Brazil \\ ${ }^{\mathrm{b}}$ Microbiology Laboratory, Biology Department, Auburn University at Montgomery - AUM, \\ P.O. Box 244023, Montgomery, Alabama, USA \\ 'Laboratório de Química Ambiental, Centro de Engenharias, Universidade Federal de Pelotas - UFPel, \\ Rua Benjamin Constant, 897, CEP 96010-020, Pelotas, RS, Brazil \\ dLaboratório de Bioremediação, Departamento de Ciência do Solo, Universidade Federal do Rio Grande do Sul - UFRGS, \\ Av. Bento Gonçalves, 7712, CEP 91541-000, Porto Alegre, RS, Brazil \\ 'Laboratório de Microbiologia de Alimentos, Departamento de Ciência de Alimentos, Universidade Federal do \\ Rio Grande do Sul - UFRGS, Av. Bento Gonçalves, 9500, CEP 91501-970, Porto Alegre, RS, Brazil \\ *e-mail: robsonandreazza@yahoo.com.br
}

Received: February 19, 2014 - Accepted: May 16, 2014 - Distributed: November 30, 2015

(With 4 figures)

\begin{abstract}
Lactic acid bacteria (LAB) have an important role in a great variety of fermented foods. In addition to their contribution to sensory characteristics, they enhance food preservation and can be used as probiotics. In this study, the antimicrobial and antioxidant activities of culture supernatants and cell free extracts of 16 LAB isolated from meat and dairy products were investigated. The bacterial were identified by $16 \mathrm{~S}$ rRNA sequencing. GenBank BLAST analysis revealed that all the isolates belong to Enterococcus faecium species. Antimicrobial activity against the indicator microorganism (Listeria monocytogenes) was observed at 11 culture supernatants and 4 cell free extracts. The sensibility of culture supernatant was evaluated by proteinase $\mathrm{K}$ and trypsin and it was observed that activity of antimicrobial substance was completely lost after the treatment. All of the isolates showed antioxidant activity as determined by the Thiobarbituric Acid Reactive Substances (TBARS) method with both types of extracts. When the antioxidant capacity was investigated using $\mathrm{ABTS}^{\cdot+}$ method (2,2 azino-bis (3-ethylbenzothiazoline-6-sulfonic acid)) and DPPH method (2,2-diphenyl-1-picrylhydrazyl) it was observed that only culture supernatants showed antioxidant capacity. These bacteria could particularly help to reduce or inhibit pathogenic microorganisms as well as oxidative spoilage in foods and feed.
\end{abstract}

Keywords: antimicrobial activity, antioxidant, Enterococcus, lactic acid bacteria, molecular characterization.

\section{Atividade antimicrobiana e antioxidante de espécies de Enterococcus isoladas de carne e produtos lácteos}

\section{Resumo}

As bactérias ácido láticas (BAL) têm um papel importante em uma grande variedade de alimentos fermentados. Em adição à sua contribuição para as características sensoriais, estes microorganismos melhoram a conservação de alimentos e podem ser utilizados como probióticos. Neste estudo, as atividades antimicrobiana e antioxidante do sobrenadante e dos extratos livres de células de 16 isolados de LAB de carne e produtos lácteos foram investigadas. Os isolados foram identificados pelo sequenciamento da região $16 \mathrm{~S}$ do rRNA. Após a comparação das sequências obtidas com aquelas disponíveis na base de dados GenBank, observou-e que todos os isolados foram pertencentes à espécie Enterococcus faecium. A atividade antimicrobiana contra o microrganismo indicador (Listeria monocytogenes) foi observada no sobrenadante das culturas em 11 isolados, e nos extratos livres de células por 4 isolados. A sensibilidade da cultura sobrenadante foi avaliada pela proteinase $\mathrm{K}$ e tripsina e observou-se que a atividade da substância antimicrobiana foi completamente perdida após o tratamento com as enzimas proteolíticas. Todos os isolados apresentaram atividade antioxidante, como determinado pelo método do ácido tiobarbitúrico de substâncias reativas (TBARS) com ambos os tipos de extratos. Quando a capacidade antioxidante foi investigada usando o método do ABTS (2,2 azino-bis (3-ethylbenzothiazoline-6-sulfonic acid)) e o método de DPPH (2,2-diphenyl-1-picrylhydrazyl) observou-se que apenas os sobrenadantes das culturas demonstraram capacidade antioxidante. Estas bactérias poderiam particularmente ajudar a reduzir ou inibir microorganismos patogênicos, bem como a deterioração oxidativa em alimentos e rações.

Palavras-chave: atividade antimicrobiana, antioxidante, Enterococcus, bactérias ácido láticas, caracterização molecular. 


\section{Introduction}

Lactic acid bacteria (LAB), which include the genera Lactococcus, Streptococcus, Lactobacillus, Pediococcus, Leuconostoc, Enterococcus, Carnobacterium and Propionibacterium, have an essential role in food fermentations (Chao et al., 2008). Besides the long history of consumption which proves the safety of consuming LAB, lactic cultures have been reported to have health-promoting characteristics that make these microorganisms desirable for use in the production of dairy and other food products (Deraz et al., 2011). The most important contribution of these microorganisms to the product is to preserve the nutritive qualities of the raw material through an extended shelf life and the inhibition of spoilage and pathogenic bacteria. This is due to competition for nutrients and the presence of inhibitors produced by the starter culture, including organic acids, hydrogen peroxide and bacteriocins (O'Sullivan et al., 2002). The ability to produce large quantities of organic acids (mainly lactic acid) through fermentation of food carbohydrates, and consequent $\mathrm{pH}$ decrease, are the fundamental factors of the antimicrobial activity of LAB. Organic acids, other inhibitory and beneficial substances, such as hydrogen peroxide, carbon dioxide, diacetyl, acetaldehyde, and bacteriocins produced by $\mathrm{LAB}$ or substances added to food, act in performance producing a broad spectrum of action against pathogenic and spoilage microorganisms (Cheng and Hoover, 2003; Monteagudo-Mera et al., 2012).

Biological systems provide favorable conditions for occurrence of oxidative reactions that are due to the existence of unsaturated lipids in the cell membranes, and due to abundance of oxidative reactions that occur during regular metabolism. The susceptibility of a cell or a tissue to oxidative stress depends on a number of factors including the availability of antioxidants and the ability for inactivation or elimination of formed oxidized products (Storz and Imlay, 1999; Lobo et al., 2010). Free radicals and other reactive oxygen species (ROS) are generated by exogenous chemicals or endogenous metabolic processes in food systems or the human body. The radicals may cause oxidative damage by oxidizing biomolecules leading to tissue damage and cell death. Atherosclerosis, cancer, emphysema, cirrhosis, and arthritis have been correlated with oxidative damage (Storz and Imlay, 1999; Kapila et al., 2006; Halliwell, 2006; Lobo et al., 2010). Therefore, oxidative damage plays a significant pathological role in human disease. However, ingestion of antioxidative supplements, or foods containing antioxidants, may reduce the oxidative damage on the human body (Wang et al., 2006).

Although, the antioxidative properties of LAB are not studied in detail, it has been shown that numerous LAB species contain NADH oxidase/peroxidase and/or catalase to prevent deleterious oxidative effects (Noonpakdee et al., 2004). The antioxidant effect of LAB in rats showing vitamin $\mathrm{E}$ deficiency was studied by Kaizu et al. (1993). The authors demonstrated that some Lactobacillus species possess antioxidant activity. Also, they are able to decrease the risk of ROS accumulation during food ingestion.
The antioxidant activity of some species of LAB has been demonstrated by in vitro enzymatic assays (Lin and Yen, 1999). The capacity to accumulate selenite $\left(\mathrm{Se}^{4+}\right)$, an essential element showing antioxidant properties (Thirunavukkarasu et al., 2004) has been described for some isolates of Enterococcus (Pieniz et al., 2011) and other LAB (Svoboda et al., 2009).

Due the overwhelming importance of LAB in foods and feed, we evaluated the antioxidant capacity and antimicrobial activity of food isolates of Enterococcus spp. characterized by molecular analysis of the $16 \mathrm{~S}$ rRNA gene sequence.

\section{Material and Methods}

\subsection{Microorganisms}

Thirty six LAB isolated from different meat and dairy products, from the collection culture of the Laboratory of Applied Microbiology and Biochemistry - ICTA, Universidade Federal do Rio Grande do Sul (Porto Alegre, Brazil), were used for selection. Many Enterococcus species were isolated from these foods (E. faecium, E. faecalis, $E$. hirae), and only E. faecium species were selected for this study. Among the sixteen isolates used in this work, isolates 2, 3, 5, 6, 7, 8, 9, 12, 17, 20, 24 and 32 were isolated from Minas Frescal (typical Brazilian soft cheese) and B22, C5, IS196 and IS197 from regional homemade sausage. Isolates were kept as frozen stock cultures in Brain Heart Infusion (BHI, Difco Laboratories, Detroit, MI, USA) broth containing 20\% (v/v) glycerol. Bacteria were grown in $\mathrm{BHI}$ broth at $37^{\circ} \mathrm{C}$ and thereafter inoculated to plates of BHI with $1.5 \%$ agar and incubated at $37^{\circ} \mathrm{C}$ for $24 \mathrm{~h}$. The indicator organism tested in this study was Listeria monocytogenes ATCC 7644.

\subsection{DNA amplification and sequencing}

Isolates were identified by a V3 region of the $16 \mathrm{~S}$ ribosomal RNA sequencing as follows. The isolates were grown on Brain Heart Infusion agar at $37^{\circ} \mathrm{C}$ for $24 \mathrm{~h}$ for evaluation of culture purity. Cells were recovered by centrifugation. DNA was extracted from the cells using Promega Wizard Genomic DNA Purification at Kit (Promega, Madison, WI, USA) with slight modification. Briefly, cells were re-suspended in $300 \mu \mathrm{L}$ of nucleic acid lysis solution, incubated at $80^{\circ} \mathrm{C}$ for $15 \mathrm{~min}$ and allowed to cool to room temperature. RNAse solution $(1.5 \mu \mathrm{L})$ was added and incubated at $37^{\circ} \mathrm{C}$ for $20 \mathrm{~min}$. Protein precipitation solution $(100 \mu \mathrm{L})$ was added and the tubes incubated on ice for $5 \mathrm{~min}$. Following centrifugation, the supernatant was transferred to a tube and $900 \mu \mathrm{L}$ ice-cold $95 \%$ ethanol was added. The precipitate was recovered by centrifugation. The pellet was washed with $70 \%$ room-temperature ethanol and re-suspended in sterile distilled water. Oligonucleotide primers corresponding to positions 27F ( 5 '-AGATTTGATCMTGGCTCAG-3') and 1492R (5'-TACGGYTACCTTGTTACGACTT-3') were used for PCR amplification of the 16S ribosomal RNA gene (Lane, 1991). The PCR reaction mixture consisted of $12.5 \mu \mathrm{L}$ of PCR master mix (Promega, Madison, WI), genomic DNA template $(0.5 \mu \mathrm{L})$, primer $27 \mathrm{~F}(2.5 \mu \mathrm{L}=12.5 \mathrm{pmol})$, 
primer $1492 \mathrm{R}(2.5 \mu \mathrm{L}=12.5 \mathrm{pmol})$ and made up to $25 \mu \mathrm{L}$ final volume with nuclease-free water. The $\mathrm{V} 3$ region of the 16S rRNA gene was amplified using a 35-cycle PCR (initial denaturation, $95^{\circ} \mathrm{C}$ for $5 \mathrm{~min}$; subsequent denaturation, $95^{\circ} \mathrm{C}$ for $0.5 \mathrm{~min}$; annealing temperature, $50^{\circ} \mathrm{C}$ for $1 \mathrm{~min}$; extension temperature, $72^{\circ} \mathrm{C}$ for $1 \mathrm{~min}$ and final extension, $72^{\circ} \mathrm{C}$ for $5 \mathrm{~min}$ ). The PCR amplification products were analyzed by electrophoresis on a $1 \%$ agarose gel. Millipore Montage PCR filter units (Millipore, Billerica, MA) were used to remove primers salts, and unincorporated dNTPs according to the manufacturer's instructions except that an additional $400 \mu \mathrm{L}$ of sterile nuclease free water was added to further remove remaining ingredients of PCR. DNA cycle sequencing was performed using BigDye terminator kit (Applied Biosystems, Foster City, CA) with sequencing primer 519r (5'-GWATTACCGCGGCKGCTG-3') in independent reactions (Institute of Integrative Genome Biology, UCR, CA).

\subsection{Phylogenetic analysis}

GenBank database was used for homology comparisons between the obtained sequences and the ones present in the database. The comparison was performed by using Basic Local Alignment Search Tool (BLAST) available online at www.ncbi.nlm.nih.gov/BLAST/. Phylogenetic and molecular evolutionary analyses were conducted using RDP release 10 software (Cole et al., 2009) and MEGA version 4.1 (Tamura et al., 2007). The rRNA sequence was submitted to the database of GenBank with respective access number as described in Figure 1A.

\subsection{Collection of cell free supernatant}

Isolates of $\mathrm{LAB}$ were inoculated to $10 \mathrm{~mL}$ of $\mathrm{BHI}$ broth and incubated at $37^{\circ} \mathrm{C}$ for $24 \mathrm{~h}$. Aliquots of the culture were transferred to $2 \mathrm{~mL}$ polypropylene tubes, and centrifuged at $10,00 \times g$ for $15 \mathrm{~min}$ at $4^{\circ} \mathrm{C}$. The resulting supernatant was neutralized ( $\mathrm{pH} 7.0$ ) with $1 \mathrm{~mol} \mathrm{~L}^{-1} \mathrm{NaOH}$ and heated at $95^{\circ} \mathrm{C}$ for $5 \mathrm{~min}$ (Bromberg et al., 2006). This culture supernatant was used to evaluate the antimicrobial and antioxidant activity.

\subsection{Preparation of intracellular extract}

Isolates of $\mathrm{LAB}$ were inoculated in $10 \mathrm{~mL}$ of $\mathrm{BHI}$ broth and incubated at $37^{\circ} \mathrm{C}$ for $24 \mathrm{~h}$. Aliquots of the culture were transferred to $2 \mathrm{~mL}$ polypropylene tubes, and centrifuged at $10,000 \times \mathrm{g}$ for $15 \mathrm{~min}$ at $4^{\circ} \mathrm{C}$. The cell pellet was washed twice with Milli-Q water and resuspended in the same water followed by ultrasonic disruption. The sonication was performed in five intervals of $1 \mathrm{~min}$ in ice bath. Cellular debris was removed by centrifugation at $10,000 \times g$ for $15 \mathrm{~min}$. The resulting supernatant was used as cell free extract to evaluate the antimicrobial and antioxidant activity.

\subsection{Antimicrobial activity}

The indicator microorganism, L. monocytogenes ATCC 7644 , was suspended in $0.85 \% \mathrm{NaCl}(\mathrm{w} / \mathrm{v})$ standardized to optical density $\left(\mathrm{OD}_{600}\right)$ of 0.150 in spectrophotometer, which corresponded to a $0.5 \mathrm{McF}$ arland turbidity standard solution. One aliquot of $20 \mu \mathrm{L}$ of culture supernatant was applied on cellulose discs ( $5 \mathrm{~mm}$ ) onto BHI agar plates previously inoculated with a swab soaked in culture of the indicator bacterium. The plates were incubated at $37^{\circ} \mathrm{C}$ and inhibition zones were measured after $24 \mathrm{~h}$. The same procedure was performed to evaluate the antimicrobial activity of cell free extracts. The diameter of inhibition zones was measured using a caliper and halos $\geq 7 \mathrm{~mm}$ were considered inhibitory (Bromberg et al., 2006). The experiment was performed in triplicate.

\subsection{Treatment of culture supernatant with proteases}

The sensibility of culture supernatant to protease was determined through sensibility of proteolytic enzyme. The proteases tested in this study were Proteinase K (Invitrogen) and Trypsin (Merck) dissolved in sterile phosphate buffer saline (PBS) at $\mathrm{pH} 7.4$ in a concentration of $10 \mathrm{mg} \mathrm{mL}^{-1}$. Fifty microlitres of each culture supernatant was mixed with $50 \mu \mathrm{L}$ of both proteases $(1: 1)$ and incubated at $37^{\circ} \mathrm{C}$ for $1 \mathrm{~h}$. Enzyme inactivation was performed by means of heat treatment with boiling water for $10 \mathrm{~min}$, and after the samples were diluted with PBS buffer (1:1). Subsequently, aliquots of $20 \mu \mathrm{L}$ were applied on cellulose discs $(6 \mathrm{~mm})$ onto BHI agar plates previously inoculated with a swab soaked in a culture of the indicator bacterium, L. monocytogenes. The plates were incubated at $37^{\circ} \mathrm{C}$ for $24 \mathrm{~h}$ and then observed for the presence or absence of inhibition zones.

\subsection{Thiobarbituric acid reactive substances (TBARS)}

The reaction to thiobarbituric acid was performed according to the methodology of Ohkawa et al. (1979). Test tubes containing Milli-Q water, extra virgin olive oil were subjected to oxidation with $100 \mu \mathrm{M}$ ferrous sulfate and incubated in a water bath at $80^{\circ} \mathrm{C}$, for $10 \mathrm{~min}$. Thereafter, to each tube was added the sample (culture supernatant and cell free extract of the bacteria), $81 \mathrm{mg} \mathrm{mL}^{-1}$ sodium lauryl sulfate (SDS), buffered acetic acid $\mathrm{pH} 3.44$ and $6 \mathrm{mg} \mathrm{mL}^{-1}$ thiobarbituric acid (TBA). The reaction mixture was further incubated in a water bath at $100^{\circ} \mathrm{C}$ for $1 \mathrm{~h}$. For each sample tested had a blank to either the culture supernatant and cell free extract, and a standard control for all comparisons. The products of reaction were determined by measurement of absorbance at $532 \mathrm{~nm}$ with a spectrophotometer. The concentration of TBARS was calculated using a standard curve developed with known concentrations of 1,1,3,3-tetramethoxypropane, and results were expressed as nmol of malonaldehyde (MDA)/mL of sample. The experiment was performed in triplicate.

\subsection{Antioxidant capacity using $\mathrm{ABTS}^{++}$method}

The antioxidant activity was determined using ABTS ${ }^{++}$ (2,2 azino-bis(3-ethylbenzothiazoline-6-sulfonic acid)) radical cation (Re et al., 1999). $\mathrm{ABTS}^{\cdot+}$ was dissolved in water $\left(7 \mathrm{~m} \mathrm{~mol} \mathrm{~L}^{-1}\right)$. ABTS radical cation $\left(\mathrm{ABTS}^{\cdot+}\right)$ was produced by reacting ABTS stock solution with $2.45 \mathrm{~m} \mathrm{~mol} \mathrm{~L}^{-1}$ potassium persulfate (final concentration) and allowing the mixture to stand in the dark at room temperature for $16 \mathrm{~h}$ before use. Stock solution was used for a maximum of 3 days. Before use, the $\mathrm{ABTS}^{-+}$solution was diluted with ethanol, to an absorbance of $0.700 \pm 0.020$ at $734 \mathrm{~nm}$. 
Samples were diluted with ethanol to obtain between $20 \%-95 \%$ inhibition of the blank absorbance. Ascorbic acid was used as the standard in the range $0-9 \mu \mathrm{g} \mathrm{mL}^{-1}$. After addition of $10 \mu \mathrm{L}$ of sample (or standards) in $1.0 \mathrm{~mL}$ of $\mathrm{ABTS}^{++}$solution, the absorbance was read at $30 \mathrm{sec}$ interval for $5 \mathrm{~min}$. Likewise, these same proportions $(10 \mu \mathrm{L}$ of supernatant of culture medium or free extract and $1.0 \mathrm{~mL}$ of $\mathrm{ABTS}^{++}$solution) were used as a control.
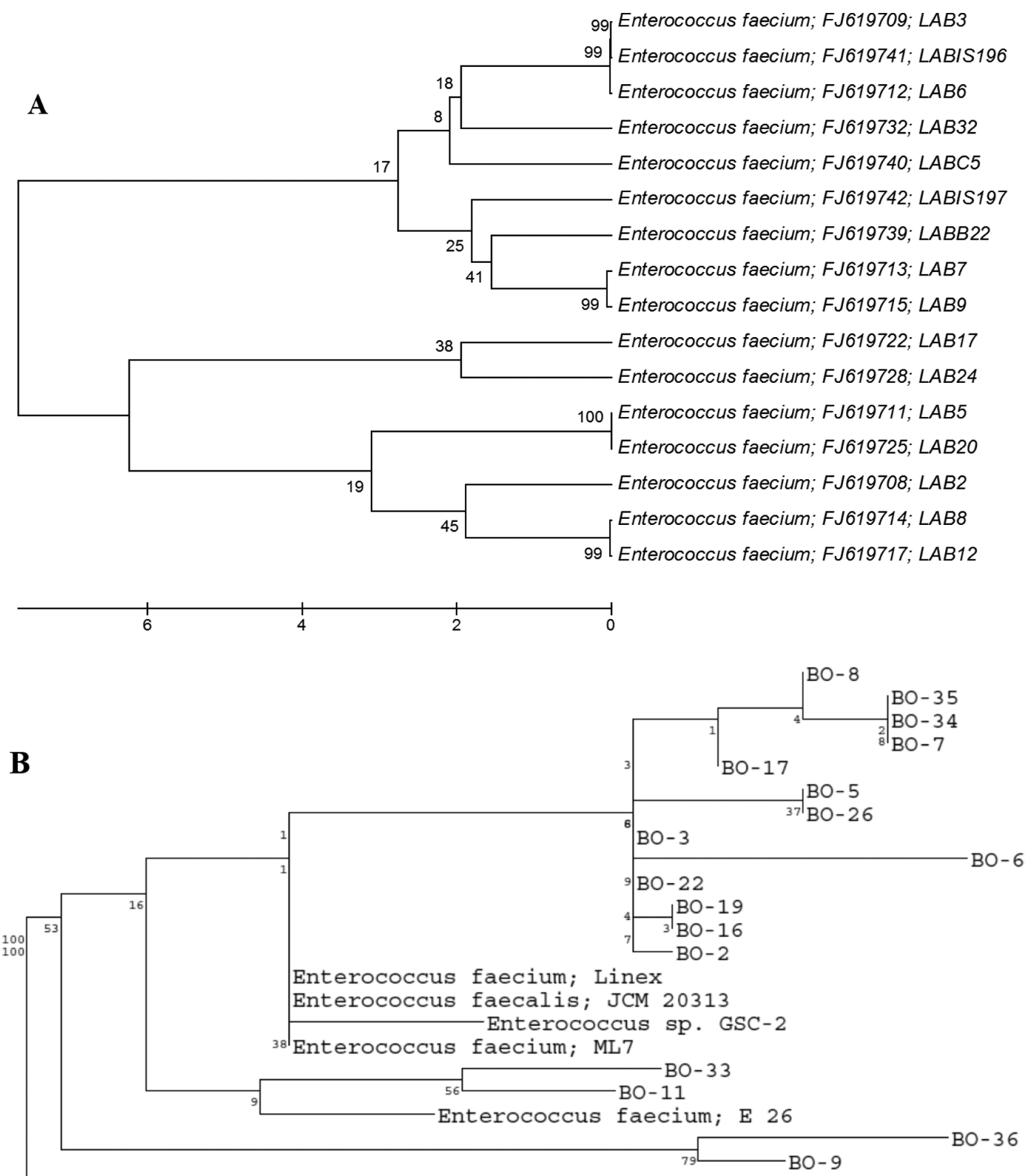

Enterococcus sp. ABRIINW-H61

Enterococcus durans (T); DSM20633

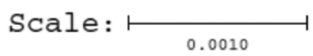

Figure 1. Phylogenetic tree (A) showing evolutionary distance between lactic acid bacterial isolates based on 16S rRNA gene sequence (500 bp). The scale represents the evolutionary distance value. The number at each node is the bootstrap from 100 replicates. (B) Phylogenetic tree showing evolutionary distance between lactic acid bacterial isolates from representative Enterococcus species using RDP release 10 software. LAB 2 (BO-2), LAB 3 (BO-3), LAB 5 (BO-5), LAB 6 (BO-6), LAB 7 (BO-7), LAB 8 (BO-8), LAB 9 (BO-9), LAB 12 (BO-11), LAB 17 (BO-16), LAB 20 (BO-19), LAB 24 (BO-22), LAB 32 (BO-26), LAB B22 (BO-33), LAB C5 (BO-34), LAB IS196 (BO-35), and LAB IS197 (BO-36). The scale represents the evolutionary distance value. The number at each node is the bootstrap from 100 replicates. 
All determinations were carried out at least three times. The percentage inhibition of absorbance at $734 \mathrm{~nm}$ was calculated using ascorbic acid standard curve.

\subsection{Scavenging ability on 2,2-diphenyl-1- picrylhydrazyl (DPPH) radicals}

The DPPH method used was as described by Brand-Williams et al. (1995) based on the capture of the DPPH (2,2-diphenyl-1-picrylhydrazyl) radical for antioxidants, producing a decrease in absorbance at $515 \mathrm{~nm}$.

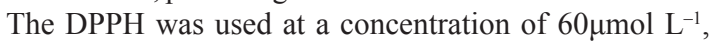
dissolved in methyl alcohol. The solution was homogenized and transferred to a dark glass bottle. The prepared solution was used only in the day of analysis. In the dark, aliquots of $0.1 \mathrm{~mL}$ of sample (culture supernatant or cell free extract) were transferred to test tubes with $3.9 \mathrm{~mL}$ of radical DPPH ( $60 \mu \mathrm{mol} \mathrm{L}{ }^{-1}$ DPPH solution) and homogenized by shaking. Likewise, these same proportions $(0.1 \mathrm{~mL}$ of culture medium or free extract and $3.9 \mathrm{~mL}$ of radical DPPH) were used as a control. Methyl alcohol was used as a blank. The standard curve was DPPH in the range 0 to $60 \mu \mathrm{mol} \mathrm{L}^{-1}$. The results were expressed as $\mathrm{EC}_{50}\left(\mu \mathrm{g} \mathrm{mL}^{-1}\right)$, which is the minimum antioxidant concentration required to reduce $50 \%$ of the initial DPPH reaction from the time the extract reached stability.

\subsection{Statistical analysis}

Means, standard deviation and standard error of replicates were performed by Excel program. Variance analysis were performed and significant results were compared by Tukey's test at $P<0.05$ with the Soc statistical Program (EMBRAPA, 1997) for TBARS and DPPH.

\section{Results}

\subsection{Bacterial identification}

All microorganisms were identified as Gram-positive and facultative anaerobic. The bacteria were identified by 16S rRNA sequence analysis as Enterococcus faecium (Figure 1). Blast analysis of 16S rRNA gene sequence revealed that isolates LAB 3, 6, 7, 9, 32, IS196 and IS197 presented $98 \%$ of similarity and the isolates LAB 2, 5, 8, $12,17,20,24$, and C5 had 99\% of similarity (Figure 1A). In general, all isolates of LAB exhibited high similarity to E. faecium (Figure 1B). The isolates LAB 2, 3, 5, 6, 7, $8,17,24,32$, C5 and IS 196 (identified in the tree as BO, $2,3,5,6,7,8,16,17,19,22,26,34$ and 35 , respectively) formed a group with high similarity to the E. faecium (Linex), and the bacteria E. durans (T) DSM20633 was the out group organism (Figure 1B).

\subsection{Antimicrobial activity}

Antimicrobial activity of culture supernatants and cell free extracts of the isolates are summarized in Table 1. Of the 16 isolates analyzed, 11 isolates displayed inhibitory activity against the indicator organism L. monocytogenes when the culture supernatant was used, and 4 isolates showed inhibitory activity with the cell free extract. Inhibitory capacity of the culture supernatants of LAB isolates against L. monocytogenes (Table 1 ) ranged from
Table 1. Antimicrobial activity of culture supernatants and cell free extracts of LAB against Listeria monocytogenes ATCC 7644.

\begin{tabular}{ccc}
\hline & \multicolumn{2}{c}{ Inhibition zone (mm) } \\
\cline { 2 - 3 } Strain & $\begin{array}{c}\text { Culture } \\
\text { Supernatant }\end{array}$ & Cell Extracts \\
\hline LAB 2 & $9.0 \pm 0.32 *$ & $0.0 \pm 0.00$ \\
LAB 3 & $7.7 \pm 0.15$ & $0.0 \pm 0.00$ \\
LAB 5 & $8.0 \pm 0.12$ & $0.0 \pm 0.00$ \\
LAB 6 & $0.0 \pm 0.00$ & $0.0 \pm 0.00$ \\
LAB 7 & $7.3 \pm 0.06$ & $0.0 \pm 0.00$ \\
LAB 8 & $0.0 \pm 0.00$ & $0.0 \pm 0.00$ \\
LAB 9 & $0.0 \pm 0.00$ & $0.0 \pm 0.00$ \\
LAB 12 & $0.0 \pm 0.00$ & $0.0 \pm 0.00$ \\
LAB 17 & $8.3 \pm 0.09$ & $8.3 \pm 0.17$ \\
LAB 20 & $0.0 \pm 0.02$ & $0.0 \pm 0.00$ \\
LAB 24 & $7.0 \pm 0.02$ & $0.0 \pm 0.00$ \\
LAB 32 & $8.0 \pm 0.18$ & $7.0 \pm 0.02$ \\
LAB B22 & $8.0 \pm 0.08$ & $0.0 \pm 0.00$ \\
LAB C5 & $7.5 \pm 0.16$ & $0.0 \pm 0.00$ \\
LAB IS196 & $10.7 \pm 0.13$ & $9.7 \pm 0.23$ \\
LAB IS197 & $11.0 \pm 0.15$ & $9.3 \pm 0.08$ \\
\hline
\end{tabular}

*Results are means \pm standard error of three independent experiments.

7.0 to $11.0 \mathrm{~mm}$. The highest inhibition zones, $10.7 \mathrm{~mm}$ and $11.0 \mathrm{~mm}$ were respectively observed with culture supernatants of isolates IS196 and IS197. The lowest zones of inhibition were recorded with culture supernatants of isolate LAB $24(7.0 \mathrm{~mm})$ and cell free extracts of isolate LAB 32. Antimicrobial activity against $L$. monocytogenes was observed in both culture supernatants and cell free extracts of LAB isolates 17, 32, IS196 and IS197. Other isolates displayed only extracellular antimicrobial activity.

The sensibility of antimicrobial activity to proteinase $\mathrm{K}$ and trypsin was evaluated. The inhibitory substance(s) produced by E. faecium isolates were inactivated by both proteolytic enzymes tested. After treatment with proteinase $\mathrm{K}$ and trypsin, the antimicrobial activity was completely lost. The control supernatants submitted only to heat treatment maintained $100 \%$ their initial activities.

\subsection{Antioxidant activity}

The antioxidant activity of both culture supernatants and cell free extracts were evaluated by different methods: TBARS, ABTS $^{++}$radical cation, and DPPH methods.

\subsubsection{Thiobarbituric acid reactive substances (TBARS)}

Both culture supernatants and cell free extracts of all LAB isolates used in this study showed antioxidant activity by the TBARS method. However, some preparations showed higher activity compared to the control, particularly culture supernatants of the E. faecium isolates 6, 7, 9, IS196 and IS197 (Figure 2A). The cell free extracts of the isolates LAB 3, 6, 8, B22, C5, IS196 and IS197 showed higher antioxidant activity (Figure $2 \mathrm{~B}$ ). 

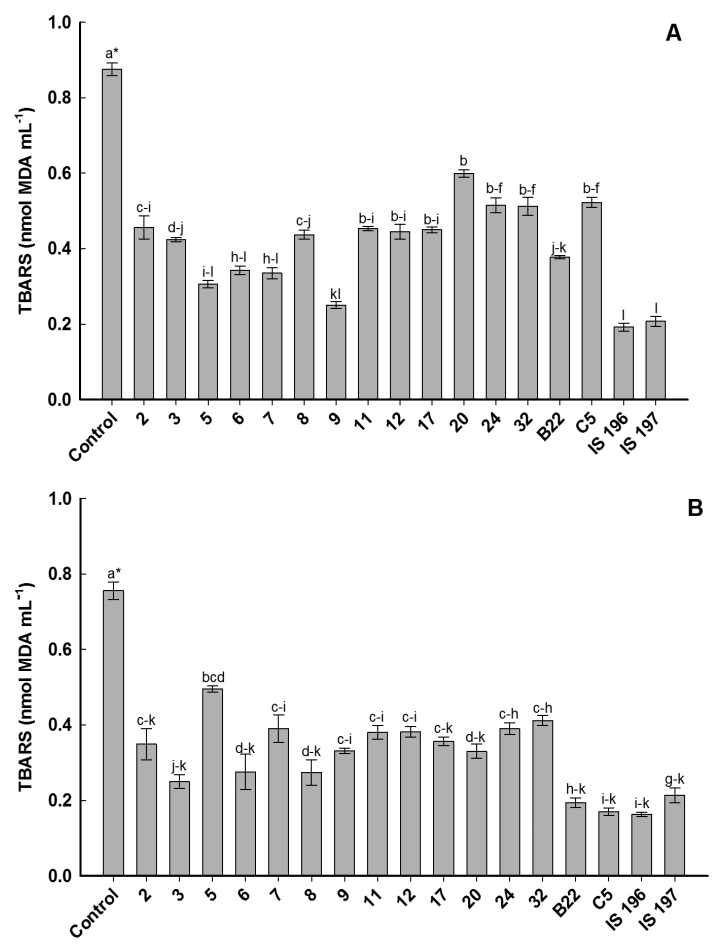

Figure 2. Evaluation of antioxidant activity of culture supernatants (A) and cell extracts (B) of isolates using thiobarbituric reactive substances (TBARS) method. Results are means \pm standard error of three independent experiments. *Different letters are significant different with 0.05 P by Tukey test. Letters separated from "-." means that are continuous, i.e. "d-k" read "defghijk".

\subsection{2. $\mathrm{ABTS}^{+}$free radical scavenging assay}

All samples of the culture supernatants showed ability to sequester free radicals by the $\mathrm{ABTS}^{-+}$method (Figure 3 ). Isolates LAB 3, 8, 12, 32, and C5 showed higher percentage of inhibition and consequently, higher antioxidant activity when compared to the other E. faecium isolates, which showed inhibitory activity between 59 and $92.5 \%$. Contrarily, samples of cell free extracts showed weak antioxidant activity with percent inhibition between 0.6 and $6 \%$ for E. faecium isolates (data not shown).

\subsubsection{Assay for DPPH radical-scavenging activity}

The results obtained with the culture supernatants are shown in Figure 4. All isolates showed antioxidant activity compared with the control $\left(\mathrm{EC}_{50}=9.77 \mu \mathrm{g} \mathrm{mL}^{-1}\right)$. $\mathrm{EC}_{50}$ values ranging from $2.41-5.02 \mu \mathrm{g} \mathrm{mL}^{-1}$ were observed with the E. faecium culture supernatants. Strain B22 displayed the lowest $\mathrm{EC}_{50}$ value $\left(2.41 \mu \mathrm{g} \mathrm{mL}^{-1}\right)$ and, consequently, higher antioxidant activities in terms of DPPH free radical scavenging. The results of cell extracts of enterococci showed no antioxidant activity measured by the DPPH free radical scavenging activity method. However, the cell extract of one strain, E. faecium strain 3, displayed significant antioxidant activity with an $\mathrm{EC}_{50}$ of $7.9 \mu \mathrm{g} \mathrm{mL}^{-1}$ (data not shown).

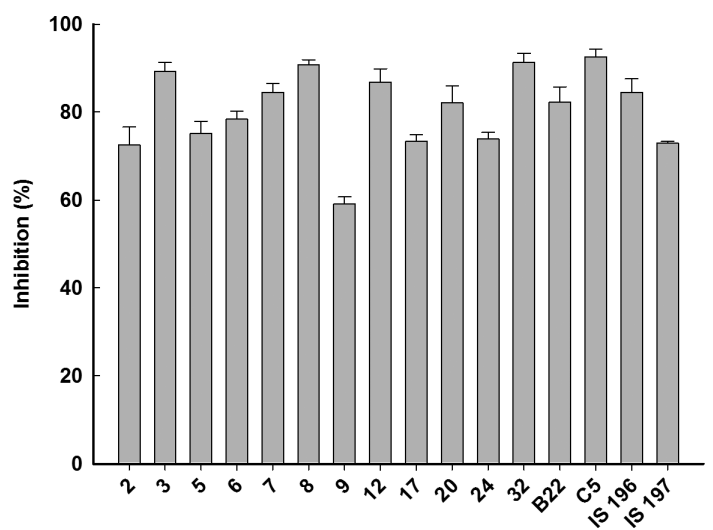

Figure 3. Determination of antioxidant capacity of culture supernatants using the $\mathrm{ABTS}^{++}$method. Results are means \pm standard error of three independent experiments.

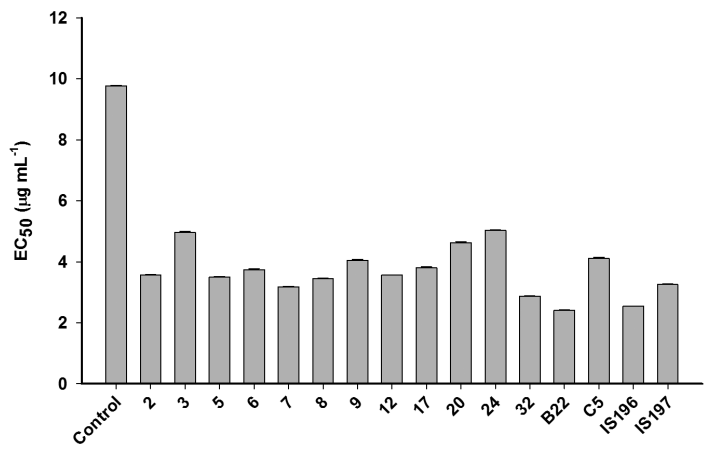

Figure 4. Determination of antioxidant capacity of culture supernatants using the DPPH method. Results are means \pm standard error of three independent experiments.

\section{Discussion}

Antimicrobial and antioxidant activities of LAB are of extreme importance in fermented foods. In this study, both antioxidant and antimicrobial activities were investigated in culture supernatants and cell free extracts of lactic acid bacteria isolated from regional dairy and meat products. The selected isolates were identified as Enterococcus faecium, which is a Gram-positive, catalase-negative cocci that share many characteristics with the genera Lactococcus and Streptococcus (Valenzuela et al., 2009). The enterococci are a complex and important group of bacteria that can be found in a variety of food products, such as milk and cheese, meat and vegetables (De Vuyst et al., 2003; Gomes et al., 2008).

The small fragment (500 bp) of the 16S rRNA gene was used to characterize the microbial community in this study. This region is called $\mathrm{V} 3$ region. The $\mathrm{V} 3$ region of $16 \mathrm{~S}$ rRNA gene is a commonly used region for bacterial phylogenetic analysis. Despite of the short nucleic acid sequences, hypervariable $\mathrm{V} 3$ region can provide information enough to describe microbial community (Liu et al., 2007). The isolates were clustered within E. faecium species, and the results obtained by $16 \mathrm{~S}$ rRNA sequencing indicated a 
high degree of sequence similarity among them and from a phylogenetically coherent group of lactic acid bacteria. Also, LAB isolates were designated to the correct species with close homology. In fact, BLAST search analyses using 16S rDNA sequence resulted in homologies between 96 and 99\%. Interestingly, Enterococcus species are frequently found in traditional fermented foods and may be included as a component of some mixed starters (Vasiljevic and Shah, 2008).

Antimicrobial activity against $L$. monocytogenes was observed in $70 \%$ of the culture supernatants of the tested isolates, indicating that antilisterial substances are secreted by these bacteria. L. monocytogenes can tolerate a wide range of $\mathrm{pH}$, temperatures, salt concentration and water activity that can be undesirable to many other bacteria. In ready-to-eat products, refrigeration is the principal method to control undesirable microorganisms in many cases and sometimes the only method of preservation. However, some psychrotrophic pathogenic microorganisms, like L. monocytogenes, can multiply with little or no change in sensory characteristics of products. Therefore, the inhibition of Listeria is very relevant to food safety since this pathogen has been associated with several disease outbreaks (Gandhi and Chikindas, 2007; Shen et al., 2013).

Antilisterial activity has been described for Enterococcus spp., which may synthesize several antimicrobial substances, such as organic acids, hydrogen peroxide, carbon dioxide, diacetyl, acetaldehyde and bacteriocins, called enterocins (Naidu et al., 1999). Although the nature of the antimicrobial substances was not determined in this study, treatment with the enzymes proteinase $\mathrm{K}$ and trypsin resulted in the inactivation of the antimicrobial activity. Thus, it seems that the antimicrobial compounds produced by E. faecium isolates are a thermostable protein or peptide showing antilisterial activity, resembling enterocins. Production of enterocins is widespread among Enterococcus spp. (Maqueda et al., 2008). Although enterocins are most frequently produced by E. faecium isolates, many other species of Enterococcus have also been found to produce bacteriocins, including $E$. faecalis, E. hirae, E. mundtii, E. durans, E. avium, E. gallinarum, E. casseliflavus and E. columbae (Sabia et al., 2004; Sánchez et al., 2007).

Several methods have been developed to evaluate antioxidant activity, including quantification of products formed during lipid peroxidation (TBARS), free radicals (ABTS $^{++}$and DPPH) scavenging assays and superoxide dismutase activity (Sanchez-Moreno et al., 1998; Frankel and Meyer, 2000; Aruoma, 2003). In this work, the in vitro antioxidant activity of the food isolated enterococci was observed by different methods, although the radical scavenging effect was only observed for culture supernatants. On contrast, free radical scavenging activity was described to intracellular extracts of some LAB, such as Lactobacillus delbrueckii (Lin and Yen, 1999), Lactobacillus acidophilus and Bifidobacterium longum (Lin and Chang, 2000).

Olive oil (monounsaturated fatty acid) was used in TBARS method as substrate and ferrous sulfate as a pro-oxidant since it can split lipid hydroperoxides. The oxidation of olive oil was inhibited by adding the samples of culture supernatants and cell free extracts, as a clear decrease in absorbance was observed resulting from the inhibition of lipid peroxidation (antioxidant activity). These results suggest that the isolates have antioxidant properties.

Although TBARS method is widely accepted, other methods for evaluation of antioxidant activity, like DPPH radical method and $\mathrm{ABTS}^{-+}$radical method, can be useful. These tests are different in relation to reaction mechanism to target radical species, reaction conditions and expression of the results. There is no universal method to evaluate antioxidant activity, thus it is necessary to use different methods to properly evaluate the antioxidant capacity (Huang et al., 2005). The antioxidant activity of culture supernatants and cell extracts were measured as capability of sequestration of free radicals, according to the $\mathrm{ABTS}^{+}$ method. This method measures the ability of the sample in sequester the radical $\mathrm{ABTS}^{\cdot+}$, compared with a standard amount of Trolox (Trolox Equivalent Antioxidant Capacity), and it is an excellent tool to determine the antioxidant activity of antioxidants and hydrogen donors terminators of antioxidants chains (Re et al., 1999).

The high antioxidant activity found in culture supernatants by ABTS $^{\cdot+}$ method was confirmed by the results obtained with the DPPH radical method. The DPPH free radical is stable but efficient antioxidant substances transfer electrons or hydrogen atoms to it neutralizing its radical character (Naik et al., 2003). Microbial antioxidants are involved in termination of free radical reactions and reducing power (Yang et al., 2000). The DPPH test provides information about the reactivity of an antioxidant with a stable free radical (Banerjee et al., 2005).

Absence of antioxidant activity in cell extracts of some isolates suggests that this property may be extracellular. It may also be due to loss of activity from the method of extraction. The effectiveness of ultrasonic disruption of microbial cells varies between organisms, and the influence of ultrasonic waves in the activity and stability of enzymes has been shown to be specific for each enzyme and dependent on parameters of sonication (Özbek and Ülgen, 2000). Detection of the antioxidant activity of these microorganisms in the culture supernatant offers a practical advantage in that it eliminates the need for free radical transport to cellular sites with antioxidant activity.

In summary, the antimicrobial and antioxidant capacities of these E. faecium isolates indicate they could be very useful in food fermentation and feed composition. They could particularly help to inhibit pathogenic microorganisms as well as oxidative spoilage in foods and feeds.

\section{Acknowldegements}

Authors thank to Coordenação de Aperfeiçoamento de Pessoal de Nível Superior (CAPES, Brazil) for scholarship to Simone Pieniz. This work received financial support of Conselho Nacional de Desenvolvimento Científico e Tecnológico (CNPq, Brazil). The thermal cycler used for PCR amplification of 16S rRNA gene of bacterial isolates was purchased with an equipment grant from Auburn University at Montgomery. 


\section{References}

ARUOMA, O.I., 2003. Methodological considerations for characterizing potential antioxidant actions of bioactive components in plant foods. Mutation Research, vol. 523-524, pp. 9-20. http:// dx.doi.org/10.1016/S0027-5107(02)00317-2. PMid:12628499.

BANERJEE, A., DASGUPTA, N.B. and DE, B., 2005. In vitro study of antioxidant activity of Syzygium cumini fruit. Food Chemistry, vol. 90, no. 4, pp. 727-733. http://dx.doi.org/10.1016/j. foodchem.2004.04.033.

BRAND-WILLIAMS, W., CUVELIER, M.E. and BERSET, C., 1995. Use of free radical method to evaluate antioxidant activity. Food Science and Technology (Campinas.), vol. 28, pp. 25-30.

BROMBERG, R., MORENO, I., DELBONI, R.R. and CINTRA, H.C., 2006. Características da bacteriocina produzida por Lactococcus lactis ssp. hordniae CTC 484 e seu efeito sobre Listeria monocytogenes em carne bovina. Ciencia e Tecnologia de Alimentos, vol. 26, no. 1, pp. 135-144. http://dx.doi.org/10.1590/ S0101-20612006000100023.

CHAO, S.H., TOMII, Y., WATANABE, K. and TSAI, Y.C., 2008. Diversity of lactic acid bacteria in fermented brines used to make stinky tofu. International Journal of Food Microbiology, vol. 123, no. 1-2, pp. 134-141. http://dx.doi.org/10.1016/j. ijfoodmicro.2007.12.010. PMid:18234387.

CHENG, H. and HOOVER, D.G., 2003. Bacteriocins and their food applications. Comprehensive Reviews in Food Science and Food Safety, vol. 2, no. 3, pp. 82-100. http://dx.doi. org/10.1111/j.1541-4337.2003.tb00016.x.

COLE, J.R., WANG, Q., CARDENAS, E., FISH, J., CHAI, B., FARRIS, R.J., KULAM-SYED-MOHIDEEN, A.S., MCGARRELL, D.M., MARSH, T., GARRITY, G.M. and TIEDJE, J.M., 2009. The ribosomal database project: improved alignments and new tools for rRNA analysis. Nucleic Acids Research, vol. 37, pp. D141-D145. http://dx.doi.org/10.1093/nar/gkn879. PMid:190 04872.

DE VUYST, L., FOULQUIE-MORENO, M.R. and REVETS, H., 2003. Screening for enterocins and detection of hemolysin and vancomycin resistance in enterococci of different origins. International Journal of Food Microbiology, vol. 84, no. 3, pp. 299-318. http://dx.doi.org/10.1016/S0168-1605(02)00425-7. PMid:12810293.

DERAZ, S.F., KHALIL, A.A. and EL-DEWANY, A.I., 2011. Booming agents for prophylaxis and therapeutic applications. World Applied Sciences Journal, vol. 14, pp. 293-323.

EMPRESA BRASILEIRA DE PESQUISA AGROPECUÁRIA - EMBRAPA. Centro Nacional de Pesquisa Tecnológica em Informática para Agricultura, 1997. Ambiente software NTIA, versão 4.2.2: manual do usuário - ferramental estatístico. Campinas: EMBRAPA

FRANKEL, E.N. and MEYER, A.S., 2000. The problems of using one-dimensional methods to evaluate multifunctional food and biological antioxidants. Journal of the Science of Food and Agriculture, vol. 80, no. 13, pp. 1925-1941. http:// dx.doi.org/10.1002/1097-0010(200010)80:13<1925::AIDJSFA714>3.0.CO;2-4.

GANDHI, M. and CHIKINDAS, M.L., 2007. Listeria: a foodborne pathogen that knows how to survive. International Journal of Food Microbiology, vol. 113, no. 1, pp. 1-15. http://dx.doi.org/10.1016/j. ijfoodmicro.2006.07.008. PMid:17010463.
GOMES, B.C., ESTEVES, C.T., PALAZZO, I.C., DARINI, A.L., FELIS, G.E., SECHI, L.A., FRANCO, B.D. and MARTINIS, E.C.P., 2008. Prevalence and characterization of Enterococcus spp. isolated from Brazilian foods. Food Microbiology, vol. 25, no. 5, pp. 668-675. http://dx.doi.org/10.1016/j.fm.2008.03.008. PMid:18541165.

HALLIWELL, B., 2006. Oxidative stress and neurodegeneration: where are we now? Journal of Neurochemistry, vol. 97, no. 6, pp. 1634-1658. http://dx.doi.org/10.1111/j.1471-4159.2006.03907.x. PMid:16805774

HUANG, D., OU, B. and PRIOR, R.L., 2005. The chemistry behind antioxidant capacity assays. Journal of Agricultural and Food Chemistry, vol. 53, no. 6, pp. 1841-1856. http://dx.doi. org/10.1021/jf030723c. PMid:15769103.

KAIZU, H., SASAKI, M., NAKAJIMA, H. and SUZUKI, Y., 1993. Effect of antioxidative lactic acid bacteria on rats fed a diet deficient in vitamin E. Journal of Dairy Science, vol. 76, no. 9, pp. 2493-2499. http://dx.doi.org/10.3168/jds.S0022-0302(93)775840. PMid:8227652.

KAPILA, S., VIBHA and SINHA, P.R., 2006. Antioxidative and hypocholesterolemic effect of Lactobacillus casei ssp casei (biodefensive properties of lactobacilli). Indian Journal of Medical Sciences, vol. 60, no. 9, pp. 361-370. http://dx.doi. org/10.4103/0019-5359.27220. PMid:16940685.

LANE, D.J., 1991. 16S/23S rRNA sequencing. In: E. STACKEBRANDT and M.N. GOODFELLOW, eds. Nucleic acid techniques in bacterial systematics. Chichester: Wiley, pp. 115-147.

LIN, M.Y. and CHANG, F.J., 2000. Antioxidative effect of intestinal bacteria Bifidobacterium longum ATCC 15708 and Lactobacillus acidophilus ATCC 4356. Digestive Diseases and Sciences, vol. 45, no. 8, pp. 1617-1622. http://dx.doi.org/10.1023/A:1005577330695. PMid:11007114.

LIN, M.Y. and YEN, C.L., 1999. Reactive oxygen species and lipid peroxidation product-scavenging ability of yogurt organisms. Journal of Dairy Science, vol. 82, no. 8, pp. 1629-1634. http:// dx.doi.org/10.3168/jds.S0022-0302(99)75391-9. PMid:10480088.

LIU, Z., LOZUPONE, C., HAMADY, M., BUSHMAN, F.D. and KNIGHT, R., 2007. Short pyrosequencing reads suffice for accurate microbial community analysis. Nucleic Acids Research, vol. 35, no. 18, pp. e120. http://dx.doi.org/10.1093/nar/gkm541. PMid:17881377.

LOBO, V., PATIL, A., PHATAK, A. and CHANDRA, N., 2010. Free radicals, antioxidants and functional foods: Impact on human health. Pharmacognosy Reviews, vol. 4, no. 8, pp. 118-126. http:// dx.doi.org/10.4103/0973-7847.70902. PMid:22228951.

MAQUEDA, M., SANCHEZ-HIDALGO, M., FERNÁNDEZ, M., MONTALBAN-LÓPEZ, M., VALDIVIA, E. and MARTÍNEZBUENO, M., 2008. Genetic features of circular bacteriocins produced by Gram-positive bacteria. FEMS Microbiology Reviews, vol. 32, no. 1, pp. 2-22. http://dx.doi.org/10.1111/j.15746976.2007.00087.x. PMid:18034824.

MONTEAGUDO-MERA, A., RODRÍGUEZ-APARICIO, L., RÚA, J., MARTIINEZ-BLANCO, H., NAVASA, N., GARCÍAARMESTO, M.R. and FERRERO, M.Á., 2012. In vitro evaluation of physiological probiotic properties of different lactic acid bacteria strains of dairy and human origin. Journal of Functional Foods, vol. 4, no. 2, pp. 531-541. http://dx.doi.org/10.1016/j.jff.2012.02.014.

NAIDU, A.S., BIDLACK, W.R. and CLEMENS, R.A., 1999. Probiotic spectra of lactic acid bacteria (LAB). Critical Reviews 
in Food Science and Nutrition, vol. 39, no. 1, pp. 13-126. http:// dx.doi.org/10.1080/10408699991279187. PMid:10028126.

NAIK, G.H., PRIYADARSINI, K.I., SATAV, J.G., BANAVALIKAR, M.M., SOHONI, D.P., BIYANI, M.K. and MOHAN, H., 2003. Comparative antioxidant activity of individual herbal components used in ayurvedic medicine. Phytochemistry, vol. 63, no. 1, pp. 97-104. http://dx.doi.org/10.1016/S0031-9422(02)00754-9. PMid:12657303

NOONPAKDEE, W., SITTHIMONCHAI, S., PANYIM, S. and LERTSIRI, S., 2004. Expression of the catalase gene katA in starter culture Lactobacillus plantarum TISTR850 tolerates oxidative stress and reduces lipid oxidation in fermented meat product. International Journal of Food Microbiology, vol. 95, no. 2, pp. 127-135. http://dx.doi.org/10.1016/j.ijfoodmicro.2004.01.020. PMid:15282125.

O'SULLIVAN, L., ROSS, R.P. and HILL, C., 2002. Potential of bacteriocin-producing lactic acid bacteria for improvements in food safety and quality. Biochimie, vol. 84, no. 5-6, pp. 593-604. http:// dx.doi.org/10.1016/S0300-9084(02)01457-8. PMid:12423803.

OHKAWA, H., OHISHI, H. and YAGI, K., 1979. Assay for lipid peroxide in animal tissues by thiobarbituric acid reaction. Analytical Biochemistry, vol. 95, no. 2, pp. 351-358. http://dx.doi. org/10.1016/0003-2697(79)90738-3. PMid:36810.

ÖZBEK, B. and ÜLGEN, K.O., 2000. The stability of enzymes after sonication. Process Biochemistry, vol. 35, no. 9, pp. 10371043. http://dx.doi.org/10.1016/S0032-9592(00)00141-2.

PIENIZ, S., OKEKE, B.C., ANDREAZZA, R. and BRANDELLI, A., 2011. Evaluation of selenite bioremoval from liquid culture by Enterococcus species. Microbiological Research, vol. 166, no. 3, pp. 176-185. http://dx.doi.org/10.1016/j.micres.2010.03.005. PMid:20634050.

RE, R., PELLEGRINI, N., PROTEGGENTE, A., PANNALA, A., YANG, M. and RICE-EVANS, C., 1999. Antioxidant activity applying an improved ABTS radical cation decolorization assay. Free Radical Biology \& Medicine, vol. 26, no. 9-10, pp. 1231-1237. http://dx.doi.org/10.1016/S0891-5849(98)00315-3. PMid:10381194.

SABIA, C., MESSI, P., DE NIEDERHAUSERN, S., MANICARDI, G. and BONDI, M., 2004. Study of two bacteriocins produced by Enterococcus casseliflavus and Enterococcus faecalis. Letters in Applied Microbiology, vol. 38, no. 2, pp. 99-105. http://dx.doi. org/10.1111/j.1472-765X.2003.01459.x. PMid:14746539.

SÁNCHEZ, J., DIEP, D.B., HERRANZ, C., NES, I.F., CINTAS, L.M. and HERNÁNDEZ, P.E., 2007. Amino acid and nucleotide sequence, adjacent genes, and heterologous expression of hiracin JM79, a sec-dependent bacteriocin produced by Enterococcus hirae DCH5, isolated from Mallard ducks (Anas platyrhynchos). FEMS Microbiology Letters, vol. 270, no. 2, pp. 227-236. http:// dx.doi.org/10.1111/j.1574-6968.2007.00673.x. PMid:17326750.
SANCHEZ-MORENO, C., LARRAURI, J.A. and SAURACALIXTO, F., 1998. A procedure to measure the antiradical efficiency of polyphenols. Journal of the Science of Food and Agriculture, vol. 76, no. 2, pp. 270-276. http://dx.doi.org/10.1002/ (SICI)1097-0010(199802)76:2<270::AID-JSFA945>3.0.CO;2-9.

SHEN, J., RUMP, L., ZHANG, Y., CHEN, Y., WANG, X. and MENG, J., 2013. Molecular subtyping and virulence gene analysis of Listeria monocytogenes isolates from food. Food Microbiology, vol. 35, no. 1, pp. 58-64. http://dx.doi.org/10.1016/j. fm.2013.02.014. PMid:23628615.

STORZ, G. and IMLAY, J.A., 1999. Oxidative stress. Current Opinion in Microbiology, vol. 2, no. 2, pp. 188-194. http://dx.doi. org/10.1016/S1369-5274(99)80033-2. PMid:10322176.

SVOBODA, M., SALÁKOVÁ, A., FAJT, Z., FICEK, R., BUCHTOVÁ, H. and DRÁBEK, J., 2009. Selenium from Seenriched lactic acid bacteria as a new Se source for growingfinishing pigs. Polish Journal of Veterinary Sciences, vol. 12, no. 3, pp. 355-361. PMid:19886257.

TAMURA, K., DUDLEY, J., NEI, M. and KUMAR, S., 2007. MEGA4: Molecular Evolutionary Genetics Analysis (MEGA) software version 4.0. Molecular Biology and Evolution, vol. 24, no. 8, pp. 1596-1599. http://dx.doi.org/10.1093/molbev/msm092. PMid:17488738.

THIRUNAVUKKARASU, C., BABU, E., EBRAHIM, A.S., CHANDRAMOHAN, N. and SAKTHISEKARAN, D., 2004. Antioxidant-associated chemoprevention by sodium selenite in $N$-nitrosodiethylamine-induced and phenobarbital-promoted hepatocarciongenesis in rats. Cell Biochemistry and Function, vol. 22, no. 4, pp. 265-271. http://dx.doi.org/10.1002/cbf.1099. PMid:15248187.

VALENZUELA, A.S., BEN OMAR, N., ABRIOUEL, H., LÓPEZ, R.L., VELJOVIC, K., CAÑAMERO, M.M., TOPISIROVIC, M.K.L. and GALVEZ, A., 2009. Virulence factors, antibiotic resistance, and bacteriocins in enterococci from artisan foods of animal origin. Food Control, vol. 20, no. 4, pp. 381-385. http:// dx.doi.org/10.1016/j.foodcont.2008.06.004.

VASILJEVIC, T. and SHAH, N.P., 2008. Probiotics - from Metchnikoff to bioactives. International Dairy Journal, vol. 18, no. 7, pp. 714-728. http://dx.doi.org/10.1016/j.idairyj.2008.03.004.

WANG, Y.C., YU, R.C. and CHOU, C.C., 2006. Antioxidative activities of soy milk fermented with lactic acid bacteria and bifidobacteria. Food Microbiology, vol. 23, no. 2, pp. 128-135. http://dx.doi.org/10.1016/j.fm.2005.01.020. PMid:16942996.

YANG, J.H., MAU, J.L., KO, P.T. and HUANG, L.C., 2000. Antioxidant properties of fermented soybean broth. Food Chemistry, vol. 71, no. 2, pp. 249-254. http://dx.doi.org/10.1016/ S0308-8146(00)00165-5. 